\title{
$\mathrm{Ti}-\mathrm{Fe}-\mathrm{Cr}$ 合金の相構成と引張特性に及ぼす $\beta$ 単相領域温度からの泠却速度の影響*1
}

\author{
池田勝彦 1 小松 伸 也 $^{1}$ 妹背 徹 1 ,*2 井上幸一郎 2
}

1関西大学工学部材料工学科

2 大同特殊鋼株式会社

J. Japan Inst. Metals, Vol. 66, No. 3 (2002), pp. 131-134

(C) 2002 The Japan Institute of Metals

\section{The Effect of Average Cooling Rate from a Temperature within Beta Single Phase Region on Phase Constitution and Tensile Properties of Ti-Fe-Cr Alloys}

Masahiko Ikeda ${ }^{1}$, Shin-ya Komatsu ${ }^{1}$, Toru Imose ${ }^{1, * 2}$ and Koichiro Inoue ${ }^{2}$

${ }^{1}$ Department of Materials Science and Engineering, Kansai University, Suita 564-8680

${ }^{2}$ Daido Steel Co., Ltd., Nagoya 457-8545

The influence of cooling rate on phase constitution and tensile properties of $\mathrm{Ti}-2.9 \mathrm{Fe}-4.9 \mathrm{Cr}$ and $\mathrm{Ti}-4.2 \mathrm{Fe}-6.9 \mathrm{Cr}$ alloys was investigated by electrical resistivity and Vickers hardness measurements, X-ray diffraction, optical microstructure observation and tensile testing.

In only Ti-2.9Fe-4.9Cr alloy quenched at an average cooling rate of $25 \mathrm{Ks}^{-1}$, reflections from isothermal omega phase were identified, whereas only reflections from beta phase were identified by XRD with no reflections of isothermal omega phase present in $\mathrm{Ti}-2.9 \mathrm{Fe}-4.9 \mathrm{Cr}$ alloy cooled at other cooling rates and $\mathrm{Ti}-4.2 \mathrm{Fe}-6.9 \mathrm{Cr}$ alloy quenched at all cooling conditions. $\mathrm{HV}$ for $\mathrm{Ti}-2.9 \mathrm{Fe}-4.9 \mathrm{Cr}$ alloy cooled at $25 \mathrm{Ks}^{-1}$, was about 400 and $\mathrm{HV}$ of $\mathrm{Ti}-4.2 \mathrm{Fe}-6.9 \mathrm{Cr}$ alloy cooled at all cooling conditions, even 25 $\mathrm{Ks}^{-1}$, was around 320 . Therefore, quench sensitivity of $\mathrm{Ti}-4.2 \mathrm{Fe}-6.9 \mathrm{Cr}$ alloy is lower than that of $\mathrm{Ti}-2.9 \mathrm{Fe}-4.9 \mathrm{Cr}$ alloy.

Tensile strength and reduction in area of $\mathrm{Ti}-2.9 \mathrm{Fe}-4.9 \mathrm{Cr}$ alloy cooled at three different cooling rates except for $25 \mathrm{Ks}^{-1}$ showed about $1200 \mathrm{MPa}$ and $45 \%$, respectively. About $1050 \mathrm{MPa}$ in $\sigma_{\mathrm{B}}$ and $60 \%$ in $\phi$ were obtained in all quenched $\mathrm{Ti}-4.2 \mathrm{Fe}-$ $6.9 \mathrm{Cr}$ alloys, respectively. The strength/ductility balances of $\mathrm{Ti}-4.2 \mathrm{Fe}-6.9 \mathrm{Cr}$ alloy quenched at four different cooling rates are comparable with those of developed beta titanium alloys in solution treated and quenched state.

(Received October 3, 2001; Accepted December 6, 2001)

Keywords: cooling rate, specimen size, low cost, isothermal $\omega$ phase, quench sensitivity, beta titanium alloys

\section{1. 緒言}

ヨーロッパを中心に高齢化が進んでいることが報告されて いる1). 日本でも, 厚生労働省では 2020 年の人口の $27 \%$ が 65 歳以上になると予想している1).この状況は高齢者用介護 用具の開発の必要性を示唆している.もちろん，障害を持つ 方々への福祉用具, 例えば車椅子などについても, 軽量で高 強度, さらに生体適合性の高い材料を使用した用具の開発は 重要である. さらに, 将来電動車椅子の需要はさらに増大す ると考えられる.つ屯り, 車椅子のフレーム材料について も, 比強度が高い材料の要求が高まるといえる. これらの条 件を兼ね備えた金属材料はチタンとその合金, さらに冷間加 工性や熱処理性の良好な $\beta$ チタン合金はそれらの応用に最 も適しているといえる.しかし，これらの合金の製造コスト が高い2)ことも知られており, 介護・福祉用具を含む民生品

*1 2001 年 9 月 24 日日本金属学会秋期大会において発表

*2 関西大学大学院生, 現在: フタバ産業侏 (Graduate Student of Kansai University, Present address: Futaba Industrial Co., Ltd.)
への応用を非常に困難なものにしている．このような民生品 への応用を可能にするためにはより低コストの $\beta$ チタン合 金を開発することが重要である.

著者らは，製鋼用材料であり低コストであるフェロクロム 合金を合金用添加材とした $\mathrm{Ti}-\mathrm{Fe}-\mathrm{Cr} \beta$ 合金を開発し，その 溶体化処理状態での強度-延性バランスが従来の $\beta$ チタン合 金，例えば Ti-15V-3Cr-3Sn-3Al 合金のそれと遜色ないこ とを見出した ${ }^{3)}$ しかしながら，本合金の合金元素である鉄 とクロムの $\beta$ 相中での拡散係数はチタンの自己拡散係数よ り大きい4ため, 試料サイズによっては $\beta$ 相領域温度からの 焼入れ途中に等温 $\omega$ 相などの析出が起こり, 機械的性質に 悪影響を与えることが懸念される.

そこで本研究では, 試料サイズ, 具体的には断面直径を変 化させた長さの同じ丸棒試料を用いて, 焼入れ時の冷却速度 を変化させ，さらに合金組成として電子/原子比を 4.20 およ び 4.28 を目標とした合金を溶製し，冷却速度と合金組成が 溶体化処理後焼入れ状態での相構成と引張特性どのように影 響するかを検討した。 
Table 1 Alloy code, chemical composition (mass\%) and ratio of electron to atom $(e / a)$ of alloys used in this study.

\begin{tabular}{ccccccc}
\hline Alloy code & $\mathrm{Fe}$ & $\mathrm{Cr}$ & $\mathrm{O}$ & $\mathrm{C}$ & $\mathrm{N}$ & $e / a$ \\
\hline $\mathrm{Ti}-2.9 \mathrm{Fe}-4.9 \mathrm{Cr}$ & 2.93 & 4.89 & 0.14 & 0.010 & 0.005 & 4.19 \\
\hline $\mathrm{Ti}-4.2 \mathrm{Fe}-6.9 \mathrm{Cr}$ & 4.21 & 6.93 & 0.14 & 0.011 & 0.008 & 4.27 \\
\hline
\end{tabular}

\section{2. 実 験 方 法}

目標 $e / a$ が 4.20 の $\mathrm{Ti}-2.9 \mathrm{Fe}-4.9 \mathrm{Cr}$ 合金と 4.28 の $\mathrm{Ti}-$ $4.2 \mathrm{Fe}-6.9 \mathrm{Cr}$ 合金はプラズマ積層凝固炉法 $(\mathrm{PPC})$ の一次溶解, VAR での再溶解後，熱間鍛造および熱間圧延で約 $25 \mathrm{~mm}$ の直径の丸棒とした。これらの工程は全て大同特殊鋼秼に依 頼した. Table 1 に合金呼称，化学組成抢よび $e / a$ を示す.

目標 $e / a$ より若干低くなった。これは溶製時にフェロクロム 合金が飛散し，目標組成より若干低くなったためである。切 削加工で直径を $10 \mathrm{~mm}, 15 \mathrm{~mm}, 20 \mathrm{~mm}$ とした．また直径 $25 \mathrm{~mm}$ 試料については受け入れ合金をそのまま用いた。丸 棒の長さは全て $70 \mathrm{~mm}$ とした．各直径の試料はマッフル炉 を用い, 大気中で $1173 \mathrm{~K}-3.6 \mathrm{ks}$ 保持後, 水水中に焼入れ た.これら焼入れ丸棒は切削加工で平行部直径 $4 \mathrm{~mm}$, 標点 距離 $30 \mathrm{~mm}$ の引張試験片とした。引張試験前に全ての引張 試験片について液体窒素温度と室温で比抵抗測定 $\left(\rho_{\mathrm{LN}}, \rho_{\mathrm{RT}}\right)$ をした ${ }^{3)}$.引張試験は室温, 大気中でクロスへッド速度 $5 \times$

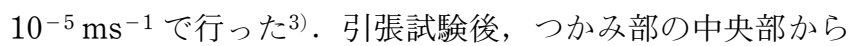
試料を採取, 整形して光学顕微鏡観察 $(\mathrm{OM}), \mathrm{X}$ 線回折によ る相同定 $(\mathrm{XRD})$ 抢よび荷重 $4.9 \mathrm{~N}$ でビッカース硬さ $(\mathrm{HV})$ を 測定した ${ }^{3)}$. また，引張試験片の破面も走査電子顕微鏡で観 察した ${ }^{3)}$.

焼入れ時の冷却速度は $\mathrm{Ti}-2.9 \mathrm{Fe}-4.9 \mathrm{Cr}$ 合金を用いて，冷 却時の時間-温度曲線を測定し，1073 K と $473 \mathrm{~K}$ との温度 間での平均冷却速度を採用した。 時間一温度曲線は次のよう にして測定した。各直径の丸棒試料の断面の中央に直径約 $3.3 \mathrm{~mm}$ ，深さ約 $35 \mathrm{~mm}$ の円筒形の穴を作製し，その穴にク ロメルーアルメル熱電対を直径約 $3 \mathrm{~mm}$ の保護管ともに挿入 し，セラミックス系接着剤で固定した。この試料を $1173 \mathrm{~K}$ で $3.6 \mathrm{ks}$ 保持後, 水水中に焼入れた時の時間一温度曲線(冷 却曲線)をペンレコーダで測定し, 解析した。 温度はデジタ ル温度計を経てペンレコーダに記録させた。解析後，図化し た時間-温度曲線(冷却曲線)を Fig. 1 に示す。また， $1073 \mathrm{~K}$ と $473 \mathrm{~K}$ 間での平均冷却速度も示してある. $473 \mathrm{~K}$ 付近か ら低温側で急激に温度が低下しているのは，セラミックス系 接着剂が割れ，穴に水が侵入したためであると考えられる. $\mathrm{Ti}-4.2 \mathrm{Fe}-6.9 \mathrm{Cr}$ 合金については，同様な測定は行っていな いが，熱的特性が大きく異ならないとして， Ti-2.9Fe$4.9 \mathrm{Cr}$ 合金の結果を用いることとした.

\section{3. 結果および考察}

Fig. 2 に平均冷却速度が $25 \mathrm{Ks}^{-1}$ と $60 \mathrm{Ks}^{-1}$ である Ti$2.9 \mathrm{Fe}-4.9 \mathrm{Cr}$ 合金と $\mathrm{Ti}-4.2 \mathrm{Fe}-6.9 \mathrm{Cr}$ 合金の光学顕微鏡組織

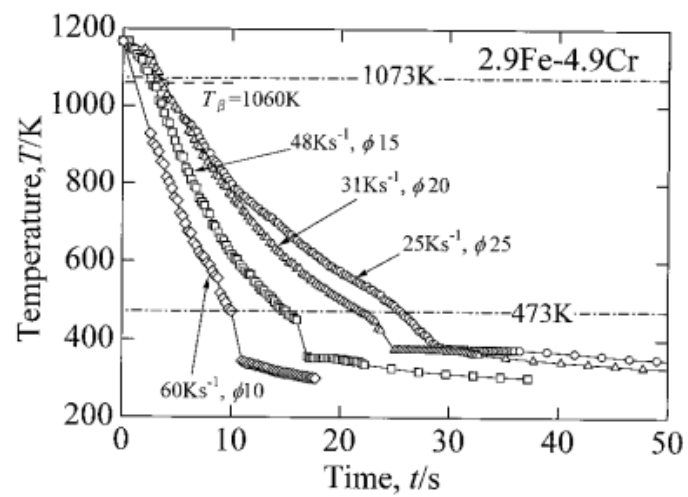

Fig. 1 Cooling curves of four different sized $\mathrm{Ti}-2.9 \mathrm{Fe}-4.9 \mathrm{Cr}$ alloy specimens after solution treatment at $1173 \mathrm{~K}$ for $3.6 \mathrm{ks}$.

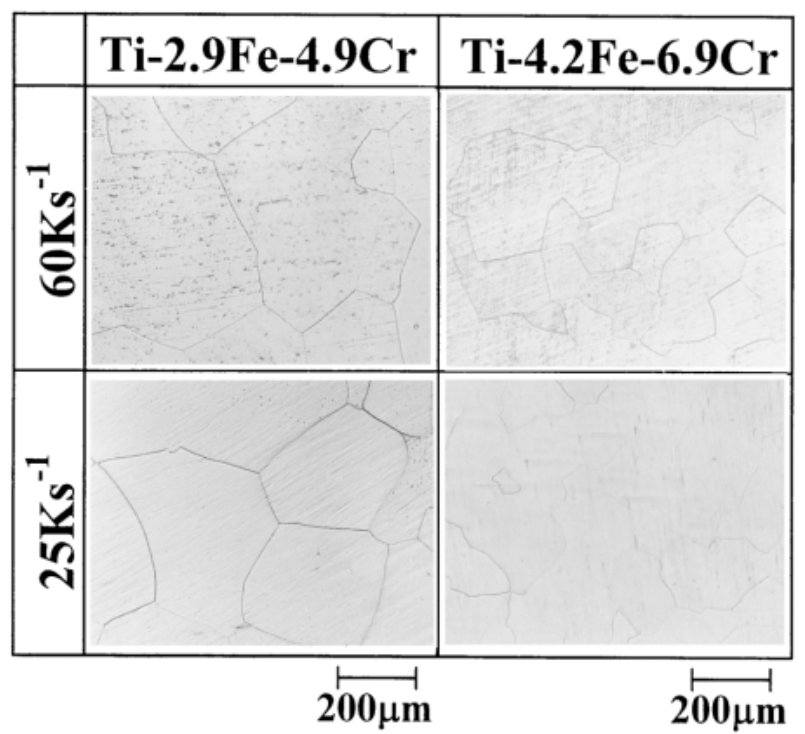

Fig. 2 Examples of optical micrographs of $\mathrm{Ti}-2.9 \mathrm{Fe}-4.9 \mathrm{Cr}$ and $\mathrm{Ti}-4.2 \mathrm{Fe}-6.9 \mathrm{Cr}$ alloys cooled at two different average cooling rates, i.e. $25 \mathrm{Ks}^{-1}$ and $60 \mathrm{Ks}^{-1}$, respectively.
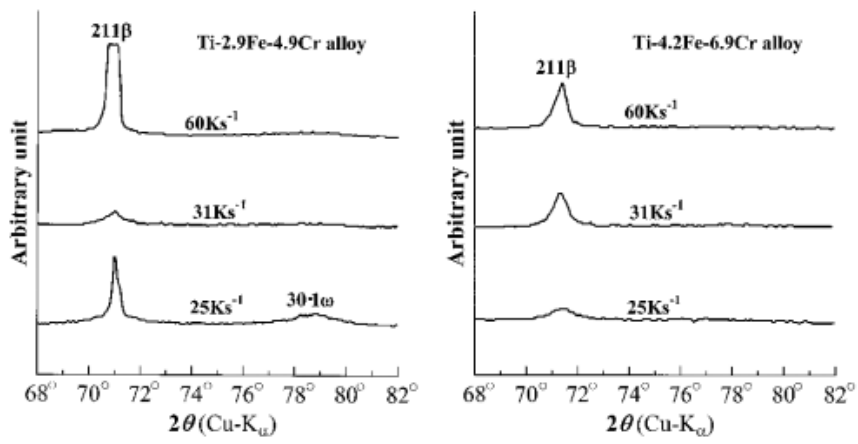

Fig. 3 Examples of X-ray diffraction profiles of $\mathrm{Ti}-2.9 \mathrm{Fe}-$ $4.9 \mathrm{Cr}$ and $\mathrm{Ti}-4.2 \mathrm{Fe}-6.9 \mathrm{Cr}$ alloys cooled at $25 \mathrm{Ks}^{-1}$.

を示す. どちらの合金も光学顕微鏡的には単相で等軸組織で あった。また，平均粒径は $\mathrm{Ti}-2.9 \mathrm{Fe}-4.9 \mathrm{Cr}$ 合金で約 270 $\mu \mathrm{m}, \mathrm{Ti}-4.2 \mathrm{Fe}-6.9 \mathrm{Cr}$ 合金で約 $160 \mu \mathrm{m}$ であった. Fig. 3 に 示すように, XRD による相同定の結果, $25 \mathrm{Ks}^{-1}$ の平均冷 却速度で冷却された $\mathrm{Ti}-2.9 \mathrm{Fe}-4.9 \mathrm{Cr}$ 合金で $\beta$ 相以外に等温 $\omega$ 相からの反射が認められた。 $\mathrm{Ti}-2.9 \mathrm{Fe}-4.9 \mathrm{Cr}$ 合金での他 

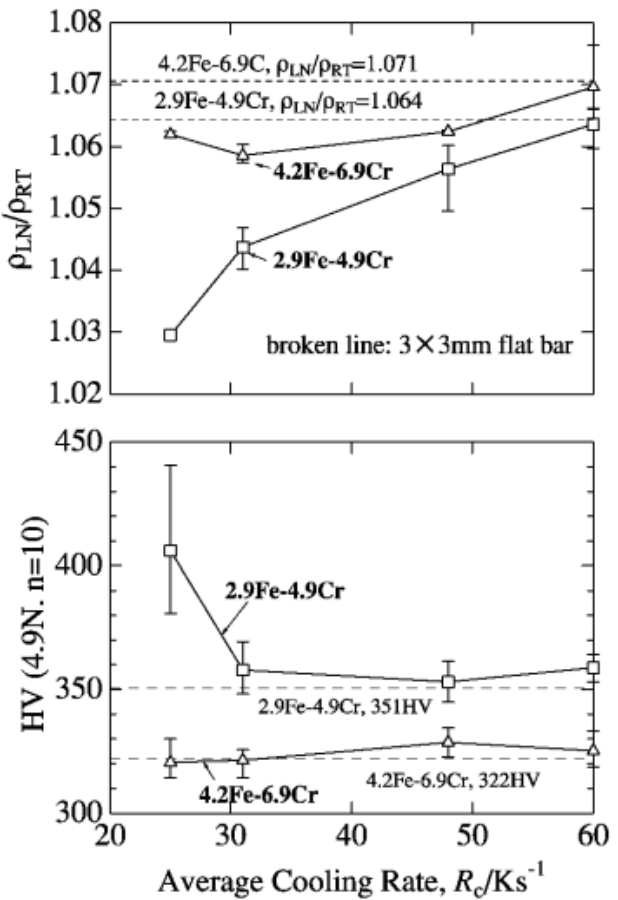

Fig. 4 Changes in resistivity ratio $\left(\rho_{\mathrm{LN}} / \rho_{\mathrm{RT}}\right)$ and Vickers hardness (HV, load; $4.9 \mathrm{~N}$ ) of $\mathrm{Ti}-2.9 \mathrm{Fe}-4.9 \mathrm{Cr}$ and $\mathrm{Ti}-4.2 \mathrm{Fe}-$ $6.9 \mathrm{Cr}$ alloys with average cooling rate, respectively.

の冷却速度の試料㧍よび $\mathrm{Ti}-4.2 \mathrm{Fe}-6.9 \mathrm{Cr}$ 合金の試料では $\beta$ 相からの反射のみが確認された。

Fig. 4 に Ti- $2.9 \mathrm{Fe}-4.9 \mathrm{Cr}$ 合金と $\mathrm{Ti}-4.2 \mathrm{Fe}-6.9 \mathrm{Cr}$ 合金の抵 抗比 $\left(\rho_{\mathrm{LN}} / \rho_{\mathrm{RT}}\right)$ と $\mathrm{HV}$ の平均冷却速度に伴う変化を示す. 破 線で示した直線は同合金の断面を約 $3 \mathrm{~mm} \times 3 \mathrm{~mm}$ とし, 長 さを約 $50 \mathrm{~mm}$ とした直方体試料で，同溶体化処理した後の 各々の測定値を示している. $\mathrm{Ti}-2.9 \mathrm{Fe}-4.9 \mathrm{Cr}$ 合金で平均冷 却速度が遅くなるに伴って抵抗比は低下し, 本研究で最も遅 い $25 \mathrm{Ks}^{-1}$ で急激に低下している。 また $\mathrm{HV} て ゙ は ， 31 \mathrm{Ks}^{-1}$ までは直方体試料のそれとほぼ同程度であったが， $25 \mathrm{Ks}^{-1}$ で急激に硬化している。これは, 前述のXRD の結果同様, 等温 $\omega$ 相が $25 \mathrm{Ks}^{-1}$ 試料で析出していることを示している. $\mathrm{Ti}-4.2 \mathrm{Fe}-6.9 \mathrm{Cr}$ 合金では, $\mathrm{Ti}-2.9 \mathrm{Fe}-4.9 \mathrm{Cr}$ 合金同様, 平均 冷却速度が遅くなるとともに抵抗比は減少するが，その減少 程度は小さく, $48 \mathrm{Ks}^{-1}$ 以下の冷却速度ではほぼ同じ值とな っている.この冷却速度以下では拡散を伴う $\beta$ 相の分解は 生じていると思われるが，その程度は初期的なもので，等温 $\omega$ 相の析出には至っていないと考えられる。これは HV が ぞの冷却速度の試料でも, 直方体試料とほぼ同程度の数值で あることからもいえる。これらの結果から, $\mathrm{Ti}-4.2 \mathrm{Fe}-$ $6.9 \mathrm{Cr}$ 合金が $\mathrm{Ti}-2.9 \mathrm{Fe}-4.9 \mathrm{Cr}$ 合金より $\beta$ 相領域温度からの 焼入れ感受性が低い, つまり $\beta$ 相の安定性が高いといえる.

Fig. 5 に Ti-2.9Fe- $4.9 \mathrm{Cr}$ 合金と $\mathrm{Ti}-4.2 \mathrm{Fe}-6.9 \mathrm{Cr}$ 合金の引 張強さ $\left(\sigma_{\mathrm{B}}\right)$, 伸び $(\boldsymbol{\delta})$ 打よび絞り $(\phi)$ と平均冷却速度の関係 を示す． $\mathrm{Ti}-2.9 \mathrm{Fe}-4.9 \mathrm{Cr}$ 合金の引張強さ，伸びおよび絞り の値は $31 \mathrm{Ks}^{-1}$ まで $60 \mathrm{Ks}^{-1}$ での值をほぼ維持したが， 25 $\mathrm{Ks}^{-1}$ では，伸びおよび絞りが減少し，その試料間でのバラ ツキも他の冷却速度の較べて大きくなった，また，若干では あるが，同冷却速度での試料で引張強さは増加した。これら

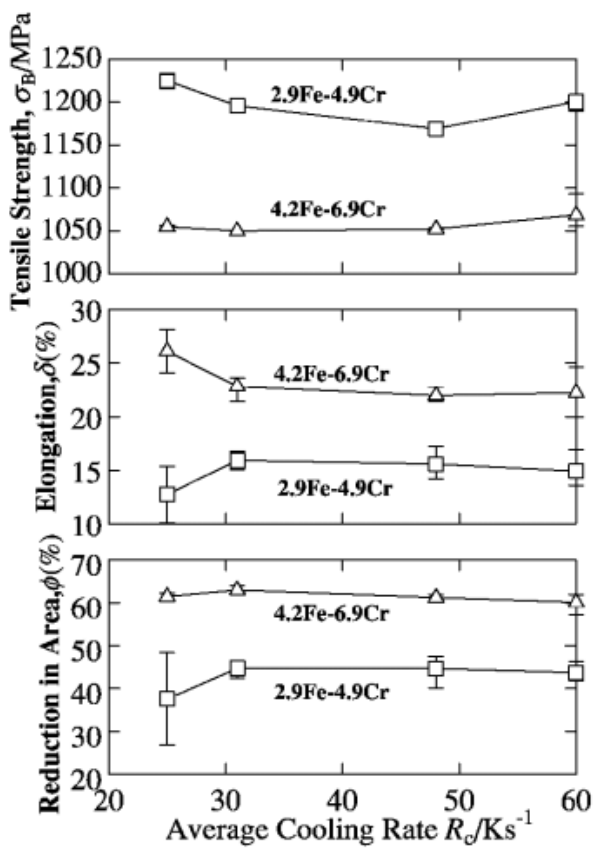

Fig. 5 Change in tensile strength $\left(\sigma_{\mathrm{B}}\right)$, elongation $(\delta)$ and reduction in area $(\phi)$ of $\mathrm{Ti}-2.9 \mathrm{Fe}-4.9 \mathrm{Cr}$ and $\mathrm{Ti}-4.2 \mathrm{Fe}-6.9 \mathrm{Cr}$ alloys with average cooling rate, respectively.

の変化は焼入れ中に析出した等温 $\omega$ 相が原因であると考え られる。しかし，等温 $\omega$ 相の析出にも関わらず，12\%程度 の伸びを示した。これは $\beta$ 相の結晶粒サイズに関係すると 思わ的 ${ }^{5)}$ が，今回の研究では明確には出来なかった，Ti$4.2 \mathrm{Fe}-6.9 \mathrm{Cr}$ 合金では, 引張強さおよび絞りは本研究で最も 遅い冷却速度である $25 \mathrm{Ks}^{-1}$ でも， $60 \mathrm{Ks}^{-1}$ の值をほぼ維持 した．伸びは $25 \mathrm{Ks}^{-1}$ で泠却した試料で若干増加したが， 他の冷却速度は $60 \mathrm{Ks}^{-1}$ の時の值をほぼ維持した。次に， $60 \mathrm{Ks}^{-1}$ の平均冷却速度で冷却された両合金の引張特性を比 較すると, $\mathrm{Ti}-2.9 \mathrm{Fe}-4.9 \mathrm{Cr}$ 合金の引張強さは $\mathrm{Ti}-4.2 \mathrm{Fe}-$ $6.9 \mathrm{Cr}$ 合金のそれより大きいが，伸び抢よび絞りでは逆に前 者の值が後者のそれらより小さくなっている. 引張強さの違 いは $\beta$ 相の安定性に伴う非熱的 $\omega$ の体積率の変化で説明で きる.つまり, 本研究の場合は $\mathrm{Ti}-2.9 \mathrm{Fe}-4.9 \mathrm{Cr}$ 合金の $\beta$ 相 安定性は $\mathrm{Ti}-4.2 \mathrm{Fe}-6.9 \mathrm{Cr}$ 合金のそれより低いため, 室温で の非熱的 $\omega$ の体積率が前者の合金が後者より大きく, HV も前者が後者より大きくなった ${ }^{6)}$.この硬さの違いが引張強 さの違いとなったと思われる．伸びおよび絞りについては， $\beta$ 結晶粒サイズが前者より後者が小さいことを考慮すること と, 変形モードについても $(332)\langle 113\rangle$ 変形双晶7)によるかす べり変形7)によるか検討する必要がある。しかし, 本研究で は変形モードまでは検討していない.

Fig. 6 に平均冷却速度が $25 \mathrm{Ks}^{-1}$ で冷却された Ti-2.9Fe$4.9 \mathrm{Cr}$ 合金と $\mathrm{Ti}-4.2 \mathrm{Fe}-6.9 \mathrm{Cr}$ 合金の引張試験後の破面の SEM 写真を示す. Ti- $-2.9 \mathrm{Fe}-4.9 \mathrm{Cr}$ 合金では，粒界破壊によ ると思われる破面も認められるが， $\mathrm{Ti}-4.2 \mathrm{Fe}-6.9 \mathrm{Cr}$ 合金で は延性破面の特徵であるディンプルのみが観察された。

Fig. 7 に Ti-2.9Fe- $4.9 \mathrm{Cr}$ 合金と $\mathrm{Ti}-4.2 \mathrm{Fe}-6.9 \mathrm{Cr}$ 合金の引 張強さと絞りの関係を示す。また, 実用 $\beta$ チタン合金の引 張強さと絞りデータから河部らによってまとめられた範囲 5 ) 


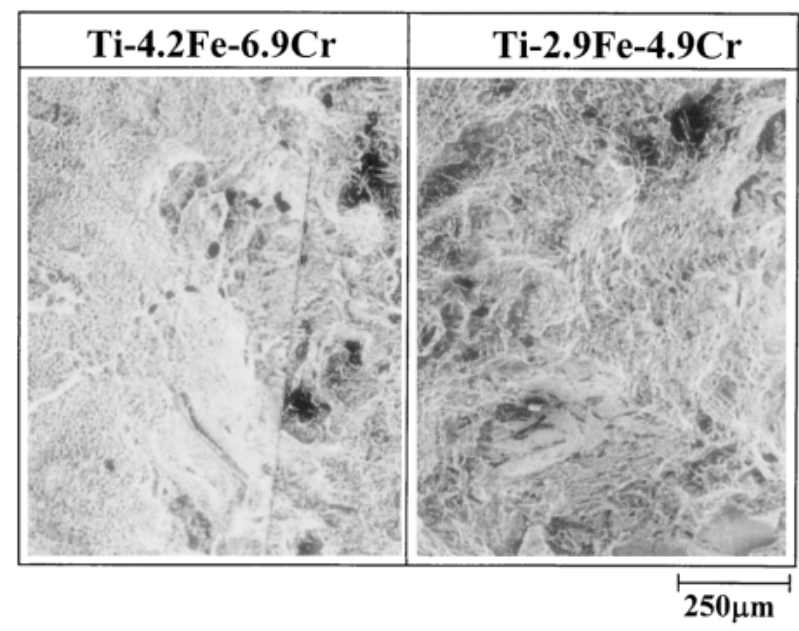

Fig. 6 Fracture surfaces of $\mathrm{Ti}-2.9 \mathrm{Fe}-4.9 \mathrm{Cr}$ and $\mathrm{Ti}-4.2 \mathrm{Fe}^{-}$ $6.9 \mathrm{Cr}$ alloys cooled at $25 \mathrm{Ks}^{-1}$, respectively.

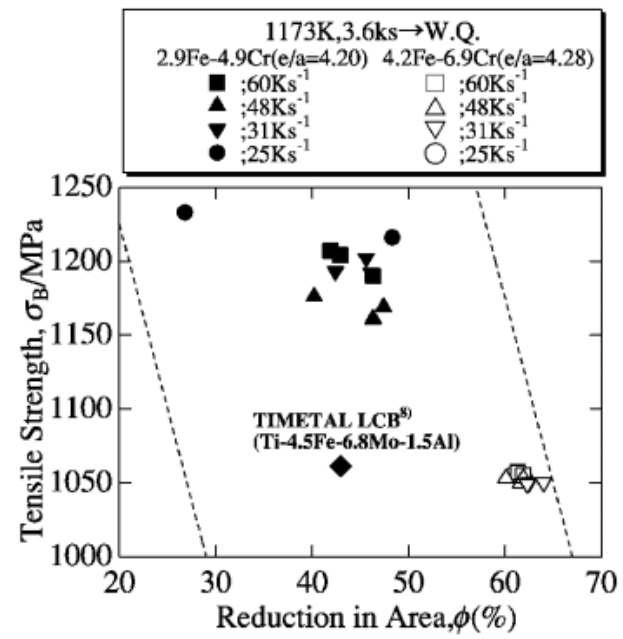

Broken line: $\sigma_{\mathrm{B}}-\phi$ balançe band of commercial $\beta$ Ti alloys ${ }^{\text {) }}$.

Fig. 7 Relationship between reduction in area $(\phi)$ and tensile strength $\left(\sigma_{\mathrm{B}}\right)$ of $\mathrm{Ti}-2.9 \mathrm{Fe}-4.9 \mathrm{Cr}$ and $\mathrm{Ti}-4.2 \mathrm{Fe}-6.9 \mathrm{Cr}$ alloys cooled at various cooling rates. The strength/ductility balance band for developed beta $\mathrm{Ti}$ alloys is also shown in this figure. This band was reported by Y. Kawabe $e t a l .{ }^{5}$.

を破線で示す。つまり，現在までに開発された $\beta$ チタン合 金の引張強さと絞りの関係はこの破線で示されたバンド内に 存在することを示している5 。さらに，低コスト $\beta$ チタン合 金として開発された Ti-4.5Fe-6.8Mo-1.5Al 合金の溶体化処 理 ·焼入れ状態での引張強さと絞りの関係もあわせて示し $た^{8)}$. 両 $\mathrm{Ti}-\mathrm{Fe}-\mathrm{Cr}$ 合金とも，いずれの冷却速度でも，得ら れた引張強さと絞りの関係は全てバンド範囲内にある．特に $\mathrm{Ti}-4.2 \mathrm{Fe}-6.9 \mathrm{Cr}$ 合金では, 冷却速度によって引張強さと絞 りの関係が大きく変化せず，安定していることが明らかとな
つた。また，既に低コスト $\beta$ チタン合金として開発されて いる $\mathrm{Ti}-4.5 \mathrm{Fe}-6.8 \mathrm{Mo}-1.5 \mathrm{Al}$ 合金の引張強さと絞りの関係と 比較すると, $\mathrm{Ti}-4.2 \mathrm{Fe}-6.9 \mathrm{Cr}$ 合金の引張強さはほぼ同じ值 であるが，その絞りは約 1.5 倍となっている. また, 冷却速 度が最も遅い $25 \mathrm{Ks}^{-1}$ 焼入れ試料を除いた $\mathrm{Ti}-2.9 \mathrm{Fe}-4.9 \mathrm{Cr}$ 合金では，ほぼ同じ絞り值で，その引張強さは約 $150 \mathrm{MPa}$ 程度高い值を示す。

以上の結果, $\mathrm{Ti}-4.2 \mathrm{Fe}-6.9 \mathrm{Cr}$ 合金では, 直径 $25 \mathrm{~mm}$ の丸 棒試料までは, $\beta$ 相領域温度からの焼入れによって, 他の実 用 $\beta$ チタン合金と遜色ない強度一延性バランスが得られる.

\section{4. 結言}

$\mathrm{Ti}-2.9 \mathrm{Fe}-4.9 \mathrm{Cr}$ 合金と $\mathrm{Ti}-4.2 \mathrm{Fe}-6.9 \mathrm{Cr}$ 合金の相構成と引 張特性に及ぼす冷却速度の影響を電気比抵抗，ビッカース硬 さ測定, X 線回折による相同定, 光学顕微鏡観察および引 張試験で検討し, 次の結果を得た. $25 \mathrm{Ks}^{-1}$ の平均冷却速度 で焼入れられた $\mathrm{Ti}-2.9 \mathrm{Fe}-4.9 \mathrm{Cr}$ 合金のみ, $\mathrm{X}$ 線回折により 等温 $\omega$ 相の反射が認められ，そのビッカース硬さは $400 \mathrm{HV}$ 以上となった． $\mathrm{Ti}-2.9 \mathrm{Fe}-4.9 \mathrm{Cr}$ 合金の他の冷却速度で焼入 れられた試料抢よび Ti-4.2Fe-6.9Cr 合金では，等温 $\omega$ 相か らの反射は認められず， $\beta$ 相のみの反射であった。これは， $\mathrm{Ti}-4.2 \mathrm{Fe}-6.9 \mathrm{Cr}$ 合金の焼入れ感受性が $\mathrm{Ti}-2.9 \mathrm{Fe}-4.9 \mathrm{Cr}$ 合金 のそれより小さいといえる. $25 \mathrm{Ks}^{-1}$ の平均冷却速度で焼入 れられた試料を除いて $\mathrm{Ti}-2.9 \mathrm{Fe}-4.9 \mathrm{Cr}$ 合金では, 引張強さ は $1200 \mathrm{MPa}$ で，伸び $15 \%$ ，絞り 45\%であった。 また，全 ての冷却速度で $\mathrm{Ti}-4.2 \mathrm{Fe}-6.9 \mathrm{Cr}$ 合金の引張強さは 1050 $\mathrm{MPa}$ ，伸び $24 \%$ ，絞り $60 \%$ であった.これらの合金，特に $\mathrm{Ti}-4.2 \mathrm{Fe}-6.9 \mathrm{Cr}$ 合金は良好な強度一延性バランスを示した。

本論文を纏めるにあたり，Imperial College の H. M. Flower 教授から有益なご意見を頂いたことに感謝します. また, 本研究の一部は, 平成 13 年度関西大学学術研究助成 基金(奨励研究)によって行った.

文献

1) Home page of Japan Ministry of Health, Labour and Welfare (2001).

2) Private communication, Mr. H. Itoh of The Japan Titanium Association.

3) M. Ikeda, S. Komatsu, T. Imose and K. Inoue: Mater. Sci. and Technol. 16 (2000) 605-608.

4) H. Nakajima and M. Koike: ISIJ Intl. 31(1991) 757-766.

5) Y. Kawabe and S. Muneki: ISIJ Intl. 31(1991) 758-791.

6) E. W. Collings: Materials Properties Handbook: Titanium Alloys, ed. by R. R. Boyer, G. Welsch and E. W. Collings, (ASM, Materials Park, 1994) pp. 102-103.

7) S. Hanada and O. Izumi: Metall. Trans. A 17A (1986) 1409-1420.

8) P. J. Bania: Beta Titanium Alloys in the 1990's, ed. by D. Eylon, R. R. Boyer and D. A. Koss, (TMS, Warrendale, 1993) pp. 3-14. 